\title{
Advances in Solid-Phase Microextraction
}

\author{
Attilio Naccarato ${ }^{1, *(D)}$ and Antonio Tagarelli ${ }^{2, *}$ \\ 1 CNR-Institute of Atmospheric Pollution Research, Division of Rende, UNICAL-Polifunzionale, \\ I-87036 Arcavacata di Rende, CS, Italy \\ 2 Dipartimento di Chimica e Tecnologie Chimiche, Università della Calabria, Via P. Bucci Cubo 12/C, \\ I-87030 Arcavacata di Rende, CS, Italy \\ * Correspondence: attilio.naccarato@iia.cnr.it (A.N.); a.tagarelli@unical.it (A.T.)
}

Received: 29 April 2020; Accepted: 26 May 2020; Published: 12 June 2020

Analysis imposes substantial challenges, especially when dealing with analytes present at trace levels in complex matrices. Although modern instrumentation has simplified analyses and made them more reliable, its use is only the last step of the whole analytical process. On the other hand, sample preparation still represents the bottleneck in many analytical methods and often requires the use of extensive protocols before instrumental analysis.

The research field of microextraction gained significance with the invention of solid-phase microextraction (SPME) in 1990 [1], which later, in 1993, became commercially available. In this technique, a small amount of extracting phase dispersed on a solid support, normally a fused-silica fiber or a metal core, is exposed to the sample, or its headspace, for a well-defined time $[2,3]$.

Since then, SPME has become a well-established sample-prep technique for simultaneous extraction and preconcentration of compounds from a variety of matrices [4-7]. Given the simplicity, versatility, and availability of different formats, SPME addresses several challenges associated with the traditional sample preparation approaches and allows for a substantial streamlining of the analytical workflow.

Over the decades, its remarkable evolution has led to new in vivo applications [8-10], development of methods for the analysis of complex matrices [4,11-14], use of new coating materials [15-19], but also development of new devices and geometries [20,21]. Although it has been recently utilized in ambient mass spectrometry, its use in conjunction with the chromatographic approaches is now consolidated, while experimental design techniques are recommended for efficient multivariate optimization of the working variables which affect the SPME performance [3,22-24].

The Special Issue described below includes six contributions provided by some of the world's leading research groups and focuses on recent advances in solid-phase microextraction.

In publication time sequence, the first contribution was submitted by Prof. Rosa Herráez-Hernández and is an article from the MINTOTA Research Group lead by Prof. Pilar Campíns-Falcó at the University of Valencia [25]. In this work, the authors explore a new material functionalized with nanoparticles as a coating for in-tube SPME. They synthesized a polymer of tetraethyl orthosilicate (TEOS) and methyltriethoxysilane (MTEOS) modified with $\mathrm{SiO}_{2}$ and $\mathrm{TiO}_{2} \mathrm{NPs}$ and used for the extraction of a variety of water pollutants, including pesticides and PAH, using both Capillary-LC and Nano-LC. The extraction efficiencies found with the synthesized coating were compared to those obtained with commercially available capillaries.

The second contribution is by Professor Verónica Pino and coworkers from the University of La Laguna, which present a review article focused on metal-organic frameworks (MOFs) as novel sorbent materials in solid-phase microextraction (SPME) [19]. This review offers an overview of the current state of the use of MOFs in different SPME configurations, in all cases covering extraction devices coated with (or incorporating) MOFs, with emphases in their preparation. Because of their outstanding properties, MOFs have been used in an increasing number of applications and the authors foresee a rise in their applicability in a variety of SPME devices in the next years. 
The third published contribution is an article by Professor Kenessov and coworkers from the Al-Farabi Kazakh National University [26]. This work is based on a method previously proposed by the same research group for the analysis of BTEX in air using $20 \mathrm{~mL}$ headspace vials and standard addition calibration and SPME-GC-MS instrumentation. The research aimed to expand this method to the quantitation of more than 20 VOCs in ambient air, which is the least addressed environmental matrix with the use of SPME. The developed method is low-cost and demonstrated its effectiveness for the assay of the chosen analytes in urban air.

The fourth contribution is a review article from the editors of the special issue and is the result of the extensive collaboration between Dr. Naccarato from CNR-Institute of Atmospheric Pollution Research Professor Tagarelli from University of Calabria [4]. This paper aims to describe the recent and most impactful applications in pollutant analysis using solid-phase microextraction (SPME) technology in environmental, food, and bioclinical analysis. The purpose of this review is to highlight the role that SPME is having in contaminant monitoring through the path that goes from the environment to humans. The covered papers were published in the last five years (2014-2019), thus, providing the reader with information about the current state-of-the-art and the future potential directions of the research in pollutant monitoring using SPME.

The last two published papers are review articles regarding two SPME cutting-edge topics such as the use of natural products as sorbent material and in vivo sampling.

The former is the result of a transcontinental collaboration between Professor Carasek's group in Brazil and the Spanish group with Professor Lucena and Professor Cardenas as senior members. This paper reviews the potential of natural products as sorbents in extraction and microextraction techniques from the synergic perspectives of the two research groups working on the topic. The reuse of materials complies with the basic principles of green analytical chemistry (GAC), which provides for the reduction/minimization of the sample treatment and the use of renewable sources when possible. The article covers the use of unmodified natural materials and the modified ones to draw a general picture of the usefulness of the materials [15].

The latter paper was submitted by Professor Bianchi and is an interesting contribution from a noteworthy Italian research group [8]. In this review, the authors provide a survey of in vivo SPME applications, which cover the state-of-the-art from 2014 up to They went through the use of miniaturized devices characterized by both commercial and lab-made coatings for in vivo SPME tissue sampling, targeted to biomarker discovery or metabolomics studies. The paper pointed out how this approach can minimize adverse effects commonly present when tissue sampling is performed by ex vivo procedures, and how the use of portable instruments and the hyphenation with sensitive techniques like ambient mass spectrometry will increase the applicability of in vivo SPME.

I hope readers will judge attractive the topics covered in this Special Issue. In this specific historical moment, we wish to conclude this editorial with a quote from Seneca:

"Honores, monumenta, quicquid aut decretis ambition iussit aut operibus exstruxit cito subruitur, nihil non longa demolitur vetustas et movet; at iis quae consecravit sapientia nocere non potest; nulla abolebit aetas, nulla deminuet" (Seneca, De brev. vit., 15,4)

It leads us to ponder how the material desires of human ambition are deteriorated by the passage of time, while wisdom and knowledge cannot be harmed, time does not erase it, nothing can diminish it. Enjoy reading.

Funding: This research received no external funding

Conflicts of Interest: The authors declare no conflict of interest. 


\section{References}

1. Arthur, C.L.; Pawliszyn, J. Solid Phase Microextraction with Thermal Desorption Using Fused Silica Optical Fibers. Anal. Chem. 1990, 62, 2145-2148. [CrossRef]

2. Pawliszyn, J. Handbook of Solid Phase Microextraction; Elsevier: Waltham, MA, USA, 2012; ISBN 9780124160170.

3. Talarico, F.; Brandmayr, P.; Giulianini, P.G.; Ietto, F.; Naccarato, A.; Perrotta, E.; Tagarelli, A.; Giglio, A. Effects of metal pollution on survival and physiological responses in Carabus (Chaetocarabus) lefebvrei (Coleoptera, Carabidae). Eur. J. Soil Biol. 2014, 61, 80-89. [CrossRef]

4. Naccarato, A.; Tagarelli, A. Recent applications and newly developed strategies of solid-phase microextraction in contaminant analysis: Through the environment to humans. Separations 2019, 6, 54. [CrossRef]

5. Carasek, E.; Morés, L.; Merib, J. Basic principles, recent trends and future directions of microextraction techniques for the analysis of aqueous environmental samples. Trends Environ. Anal. Chem. 2018, 19, e00060. [CrossRef]

6. Roszkowska, A.; Miękus, N.; Bączek, T. Application of solid-phase microextraction in current biomedical research. J. Sep. Sci. 2019, 42, 285-302. [CrossRef]

7. Dinoi, A.; Cesari, D.; Marinoni, A.; Bonasoni, P.; Riccio, A.; Chianese, E.; Tirimberio, G.; Naccarato, A.; Sprovieri, F.; Andreoli, V.; et al. Inter-Comparison of Carbon Content in PM2.5 and PM10 Collected at Five Measurement Sites in Southern Italy. Atmosphere 2017, 8, 243.

8. Riboni, N.; Fornari, F.; Bianchi, F.; Careri, M. Recent advances in in vivo spme sampling. Separations 2020, 7, 6. [CrossRef]

9. Naccarato, A.; Cavaliere, F.; Tassone, A.; Brandmayr, P.; Tagarelli, A.; Pirrone, N.; Sprovieri, F.; Giglio, A. In vivo solid-phase microextraction gas chromatography-mass spectrometry (SPME-GC-MS) assay to identify epicuticular profiles across task groups of Apis mellifera ligustica workers. J. Entomol. Acarol. Res. 2019, 51, 468-481. [CrossRef]

10. Bonacci, T.; Mazzei, A.; Naccarato, A.; Elliani, R.; Tagarelli, A.; Brandmayr, P. Beetles "in red": Are the endangered flat bark beetles Cucujus cinnaberinus and $\mathrm{C}$. haematodes chemically protected? (Coleoptera: Cucujidae). Eur. Zool. J. 2018, 85, 129-137. [CrossRef]

11. Huang, S.; Chen, G.; Ye, N.; Kou, X.; Zhu, F.; Shen, J.; Ouyang, G. Solid-phase microextraction: An appealing alternative for the determination of endogenous substances-A review. Anal. Chim. Acta 2019, 1077, 67-86. [CrossRef]

12. Kenessov, B.; Koziel, J.A.; Bakaikina, N.V.; Orazbayeva, D. Perspectives and challenges of on-site quantification of organic pollutants in soils using solid-phase microextraction. TrAC-Trends Anal. Chem. 2016, 85, 111-122. [CrossRef]

13. Naccarato, A.; Gionfriddo, E.; Elliani, R.; Sindona, G.; Tagarelli, A. A fast and simple solid phase microextraction coupled with gas chromatography-triple quadrupole mass spectrometry method for the assay of urinary markers of glutaric acidemias. J. Chromatogr. A 2014, 1372, 253-259. [CrossRef] [PubMed]

14. Gionfriddo, E.; Naccarato, A.; Sindona, G.; Tagarelli, A. A reliable solid phase microextraction-gas chromatography-triple quadrupole mass spectrometry method for the assay of selenomethionine and selenomethylselenocysteine in aqueous extracts: Difference between selenized and not-enriched selenium potatoes. Anal. Chim. Acta 2012, 747, 58-66. [CrossRef] [PubMed]

15. Mafra, G.; García-Valverde, M.T.; Millán-Santiago, J.; Carasek, E.; Lucena, R.; Cárdenas, S. Returning to Nature for the Design of Sorptive Phases in Solid-Phase Microextraction. Separations 2019, 7, 2. [CrossRef]

16. Naccarato, A.; Pawliszyn, J. Matrix compatible solid phase microextraction coating, a greener approach to sample preparation in vegetable matrices. Food Chem. 2016, 206, 67-73. [CrossRef] [PubMed]

17. Naccarato, A.; Gionfriddo, E.; Elliani, R.; Pawliszyn, J.; Sindona, G.; Tagarelli, A. Investigating the robustness and extraction performance of a matrix-compatible solid-phase microextraction coating in human urine and its application to assess 2-6-ring polycyclic aromatic hydrocarbons using GC-MS/MS. J. Sep. Sci. 2018, 41, 929-939. [CrossRef] [PubMed]

18. Lashgari, M.; Yamini, Y. An overview of the most common lab-made coating materials in solid phase microextraction. Talanta 2019, 191, 283-306. [CrossRef]

19. Gutiérez-Serpa, A.; Pacheco-Fernández, I.; Pasán, J.; Pino, V. Metal-Organic Frameworks as Key Materials for Solid-Phase Microextraction Devices-A Review. Separations 2019, 6, 47. 
20. Sajid, M.; Khaled Nazal, M.; Rutkowska, M.; Szczepańska, N.; Namieśnik, J.; Płotka-Wasylka, J. Solid Phase Microextraction: Apparatus, Sorbent Materials, and Application. Crit. Rev. Anal. Chem. 2019, 49, 271-288. [CrossRef]

21. Psillakis, E. Vacuum-assisted headspace solid-phase microextraction: A tutorial review. Anal. Chim. Acta 2017, 986, 12-24. [CrossRef]

22. Naccarato, A.; Elliani, R.; Cavaliere, B.; Sindona, G.; Tagarelli, A. Development of a fast and simple gas chromatographic protocol based on the combined use of alkyl chloroformate and solid phase microextraction for the assay of polyamines in human urine. J. Chromatogr. A 2018, 1549, 1-13. [CrossRef] [PubMed]

23. Naccarato, A.; Tassone, A.; Moretti, S.; Elliani, R.; Sprovieri, F.; Pirrone, N.; Tagarelli, A. A green approach for organophosphate ester determination in airborne particulate matter: Microwave-assisted extraction using hydroalcoholic mixture coupled with solid-phase microextraction gas chromatography-tandem mass spectrometry. Talanta 2018, 189, 657-665. [CrossRef] [PubMed]

24. Naccarato, A.; Elliani, R.; Sindona, G.; Tagarelli, A. Multivariate optimization of a microextraction by packed sorbent-programmed temperature vaporization-gas chromatography-tandem mass spectrometry method for organophosphate flame retardant analysis in environmental aqueous matrices. Anal. Bioanal. Chem. 2017, 409, 7105-7120. [CrossRef] [PubMed]

25. Serra-Mora, P.; García-Narbona, P.; Verdú-Andrés, J.; Herráez-Hernández, R.; Campíns-Falcó, P. Exploring new extractive phases for in-tube solid phase microextraction coupled to miniaturized liquid chromatography. Separations 2019, 6, 12. [CrossRef]

26. Ibragimova, O.P.; Baimatova, N.; Kenessov, B. Low-cost quantitation of multiple volatile organic compounds in air using solid-phase microextraction. Separations 6. [CrossRef]

(C) 2020 by the authors. Licensee MDPI, Basel, Switzerland. This article is an open access article distributed under the terms and conditions of the Creative Commons Attribution (CC BY) license (http://creativecommons.org/licenses/by/4.0/). 